\title{
Perbedaan Hasil Belajar Matematika Menggunakan Model Pembelajaran Make a Match dan Model Pembelajaran Pair Checks
}

\author{
Luthfiah Lintang ${ }^{1}$, Lelya Hilda, Nur Fauziah Siregar \\ ${ }^{1}$ IAIN Padangsidimpuan \\ ${ }^{1}$ luthfiahlintang@gmail.com
}

\begin{tabular}{l}
\hline \hline Article Info \\
\hline Article history: \\
Received April $1^{\text {st }}, 2021$ \\
Revised June $29^{\text {th }}, 2021$ \\
Accepted July $2^{\text {nd }}, 2021$ \\
\hline
\end{tabular}

Keywords:

Mathematics Learning

Outcomes;

Make a Match Learning

Model;

Pair Checks Learning

Model

This study aims to determine the significant difference between the learning outcomes of mathematics using the model Make a Match learning and Pair Checks learning model on the integer material in class VII MTs IB Silaping. This type of research is a comparative study with experimental methods. The population in this study were students of class VII MTs IB Silaping totaling 92 students. The sample of this research is class $\mathrm{VII}_{2} b$ as the experimental class 1 and class $V I I_{1}$ a as the experimental class 2 with the same number of 16 students. The samples were determined by nonprobability sampling. The data collection instrument is a test. The data analysis technique used is the normality test, homogeneity test, and to test the hypothesis with the t-test. The results of this study indicate that: (1) mathematics learning outcomes using the Make a Match learning model with an average value of 86,88; (2) mathematics learning outcomes using the Pair Checks learning model with an average value of 80,56. So it can be concluded that (3) there is a significant difference between the learning outcomes of mathematics using the Make a Match learning model and the Pair Checks learning model on the integer material in class VII MTs IB Silaping. This is in accordance with the calculation of the t-test which is obtained at the significant level $\alpha=0,05$ and $d k=30$ with $t_{\text {count }}=2,433$ and $t_{\text {table }}=2,042$ this indicates that $t_{\text {count }}>t_{\text {table }}$.

Kata Kunci:

Hasil Belajar

Matematika;

Model Pembelajaran

Make a Match;

\section{Abstrak}

Penelitian ini bertujuan untuk mengetahui perbedaan yang signifikan antara hasil belajar Matematika dengan menggunakan model pembelajaran Make a Match dan model pembelajaran Pair Checks pada materi bilangan bulat di kelas VII MTs IB Silaping. Jenis penelitian ini 
Model Pembelajaran Pair Checks adalah penelitian komparasi dengan metode eksperimen. Populasi dalam penelitian ini adalah siswa kelas VII MTs IB Silaping yang berjumlah 92 siswa. Sampel penelitian ini adalah kelas $\mathrm{VII}_{2}$ b sebagai kelas eksperimen 1 dan kelas VII $_{1}$ a sebagai kelas eksperimen 2 dengan jumlah yang sama yaitu 16 siswa. Penentuan sampel ditentukan dengan non-probability sampling. Instrumen pengumpulan data yaitu tes. Teknik analisis data yang digunakan yaitu uji normalitas, uji homogenitas, dan untuk menguji hipotesis dengan uji-t. Hasil penelitian ini menunjukkan bahwa (1) hasil belajar matematika dengan menggunakan model pembelajaran Make a Match dengan nilai rata-rata 86,88; (2) hasil belajar matematika dengan menggunakan model pembelajaran Pair Checks dengan nilai rata-rata 80,56. Sehingga diperoleh kesimpulan bahwa (3) terdapat perbedaan yang signifikan antara hasil belajar matematika dengan menggunakan model pembelajaran Make a Match dan model pembelajaran Pair Checks pada materi bilangan bulat dikelas VII MTs IB Silaping. Hal ini sesuai dengan perhitungan uji $t$ yaitu diperoleh pada taraf signifikansi $\alpha=0,05$ dan $\mathrm{dk}=30$ dengan $t_{\text {hitung }}=2,433$ dan $t_{\text {tabel }}=2,042$ ini menunjukkan bahwa $t_{\text {hitung }}>\mathrm{t}_{\text {tabel. }}$.

\section{PENDAHULUAN}

Pendidikan merupakan seperangkat hasil yang dicapai oleh peserta didik setelah diselenggarakannya kegiatan pendidikan. Tujuan pendidikan dapat dijabarkan mulai dari tujuan nasional, institusional, kurikuler, sampai instruksional (Hamalik, 2011). Pendidik mempunyai tanggung jawab yang besar dalam mencapai tujuan pendidikan.

Belajar merupakan proses yang terjadi dalam diri individu yang berinteraksi pada lingkungan untuk mendapatkan perubahan dalam tingkah lakunya. Proses belajar merupakan proses yang unik dan kompleks. Keunikan itu disebabkan karena hasil belajar hanya terjadi pada individu yang belajar, tidak pada orang lain, dan setiap individu menampilkan perilaku belajar yang berbeda (Purwanto, 2017). Sehingga siswa adalah penentu terjadinya atau tidak terjadinya proses belajar. Guru dan siswa harus saling bekerjasama dalam proses pembelajaran agar 
tercapainya proses pembelajaran yang efektif. Oleh sebab itu guru dan siswa memiliki hubungan yang erat dalam pencapaian hasil belajar.

Berdasarkan hasil observasi awal yang peneliti lakukan terhadap pelaksanaan pembelajaran matematika di MTs IB Silaping ditemukan permasalahan bahwa pada umumnya dalam kegiatan pembelajaran masih banyak ditemukan siswa yang kurang aktif mengikuti pembelajaran di kelas, terutama pada mata pelajaran matematika. Siswa menganggap bahwa matematika itu sulit dimengerti, dipahami, dan sungguh membosankan dipelajari. Salah satu faktor yang menyebabkan siswa kurang menyukai mata pelajaran matematika adalah guru masih cenderung menggunakan pembelajaran konvensional (Ainur, 2016). Dimana pembelajaran konvensional ini cenderung guru yang menjelaskan dan siswa kurang aktif dalam pembelajaran. Hal ini bertentangan dengan teori pembelajaran konstruktivisme yang menganjurkan peran siswa yang lebih aktif, peran guru dalam kelas yang berpusat pada siswa hanya semata membantu siswa menemukan fakta, konsep, atau prinsip bagi mereka sendiri (Pianda, 2018).

Berdasarkan wawancara peneliti dengan ibu Roha Nami salah satu guru matematika kelas VII di MTs IB Silaping ditemukan bahwa hasil belajar matematika siswa cenderung rendah disebabkan oleh beberapa faktor yaitu pertama, faktor internal yaitu faktor yang berasal dari siswa itu sendiri seperti ketidaktertarikan siswa dalam belajar matematika mengakibatkan hasil belajar siswa tergolong rendah. Kurangnya kemauan siswa belajar materi matematika selama proses pembelajaran menyebabkan mereka gagal dalam belajar matematika. Kedua, faktor eksternal yaitu guru kurang menggunakan model, strategi dan media yang inovatif dalam proses pembelajaran berlangsung yang menyebabkan siswa lebih pasif dalam proses pembelajaran. Dalam hal ini siswa masih ada yang kurang paham dalam mata pelajaran matematika seperti pada materi bilangan bulat yang disampaikan guru karena guru cenderung lebih aktif dalam proses pembelajaran daripada siswanya karena kurangnya guru menggunakan model yang tepat dalam menghasilkan hasil belajar matematika siswa yang baik. Mata pelajaran matematika bukan hanya sekedar teori abstrak yang dapat mengantarkan ketidakbermaknaan yang 
dirasakan oleh siswa, akan tetapi mata pelajaran yang dalam proses pembelajaran dibuat lebih bermakna yang dapat diaplikasikan dalam kehidupan sehari-hari, sehingga dapat menunjukkan suatu prestasi yang dilihat bukan hanya sekedar nilai (Siregar, 2020).

Dalam belajar bilangan bulat siswa menganggap bahwa bilangan bulat adalah bilangan bulat saja dan tidak terpecah (dalam bentuk desimal) tetapi dalam kenyataannya siswa kurang mampu dalam mengingat konsep bilangan bulat itu terdiri dari bilangan bulat negatif, nol, dan bilangan bulat positif. Pada saat wawancara juga diperoleh nilai Kriteria Ketentuan Minimum (KKM) yang digunakan di MTs IB Silaping adalah 75 untuk siswa kelas VII. Hasil belajar siswa tergolong rendah sebab banyak dari siswa yang belum mencapai nilai KKM pada materi bilangan bulat. Siswa tidak mampu mencapai nilai KKM karena siswa mengalami kesulitan dalam belajar bilangan bulat.

Rendahnya hasil belajar siswa pada materi bilangan bulat juga dikemukakan oleh Karomah dan Sudiman (2013) yang menyatakan bahwa dari 24 siswa kelas $\mathrm{V}$ yang mengikuti evaluasi di akhir pembelajaran tentang penjumlahan bilangan bulat, hanya 54,17\% siswa yang mencapai KKM 70. Penyebabnya adalah kurang aktifnya siswa dalam pembelajaran matematika. Sejalan dengan hasil penelitian Karomah \& Sudiman, observasi awal yang dilakukan Iqbal dan Karim (2018) menemukan bahwa rendahnya kemampuan siswa dalam menyelesaikan permasalahan matematika pada materi bilangan bulat disebabkan oleh pembelajaran yang dilakukan guru belum membuat siswa aktif, saling bekerja sama, menyatukan pikiran, dan menghargai pendapat orang lain.

Untuk mengatasi permasalahan di atas perlu mencari model pembelajaran yang dapat meningkatkan keaktifan siswa dan meningkatkan hasil belajar siswa. Pemilihan dan penerapan pembelajaran matematika yang diberikan guru merupakan hal yang penting untuk diperhatikan, dengan pembelajaran matematika yang tepat akan membuat matematika disukai oleh siswa (Siregar, 2016). Salah satunya dengan menggunakan model pembelajaran Make a Match dan model pembelajaran Pair Checks. Peneliti tertarik untuk menggunakan kedua 
model ini sebab model pembelajaran Make a Match dan Pair Checks merupakan pendekatan model kooperatif yang sukses pada tim-tim kecil (Gillies, 2016). Pada dasarnya banyak siswa yang berhasil dalam pembelajaran lewat model tersebut tetapi ada juga siswa yang tidak berhasil. Sehingga peneliti ingin membandingkan dari kedua model pembelajaran tersebut manakah yang lebih baik diterapkan dalam pembelajaran Matematika yaitu bilangan bulat.

Model pembelajaran Make a Match baik diterapkan pada kelompok-kelompok kecil karena pada model ini siswa diminta untuk mencari pasangan kartu yang merupakan kartu jawaban atau pertanyaan materi tertentu dalam pembelajarannya. Dengan model ini siswa aktif dalam mengikuti pembelajaran sehingga dapat mempunyai pengalaman yang bermakna (Yudhanegara, 2015). Model pembelajaran ini termasuk dalam teori belajar Vygotsky (Danoebroto, 2015) dan teori belajar Behavioristik (Nahar, 2016). Berdasarkan penelitian (Santi Ariati, 2019) menunjukkan bahwa model pembelajaran kooperatif teknik Make a Match memiliki pengaruh terhadap hasil belajar matematika siswa, karena dengan model pembelajaran kooperatif teknik Make a Match ini siswa merasa tidak bosan dalam pembelajaran berlangsung. Dengan adanya model pembelajaran kooperatif teknik Make a Match ini siswa dilatih dalam berfikir untuk menemukan kartu pertanyaan dan jawaban yang dapat mempengaruhi keaktifan siswa dan hasil belajar matematika siswa tersebut.

Sedangkan model pembelajaran Pair Checks merupakan model pembelajaran dimana siswa saling berpasangan dalam menyelesaikan persoalan yang diberikan dengan berbantuan LKS. Dimana model pembelajaran ini termasuk dalam teori belajar konstruktivisme (Pianda, 2018). Dalam model pembelajaran ini guru dan siswa saling berkaitan dimana guru sebagai motivator dan fasilitator sedangkan siswa tersebut dilatih untuk memiliki rasa sosial, kerjasama dan mampu memberikan penilaian (Shoimin, 2014). Berdasarkan penelitian Rohmatika bahwa model pembelajaran kooperatif tipe Pair Checks dengan bantuan Lembar Kerja Siswa (LKS) dapat meningkatkan hasil belajar matematika siswa, dikarenakan dalam proses pembelajaran siswa lebih aktif, kedekatan antar 
siswa, belajar menerima pendapat orang lain, dan termotivasi dalam mengerjakan soal yang diberikan sehingga membuat siswa lebih semangat dalam belajar (Rohmatika, 2017).

Secara teoritis kedua model ini sangat bagus diterapkan dan dilihat dari penelitian sebelumnya. Kedua model pembelajaran ini memiliki pengaruh terhadap hasil belajar matematika siswa karena setiap model memiliki kelebihan dan kekurangannya masing-masing. Perbedaan kedua model ini terletak pada langkah-langkah pembelajaran dan dalam hasil belajar matematika yang dicapai namun belum diketahui seberapa besar perbedaan tersebut.

\section{METODE PENELITIAN}

Jenis penelitian ini menggunakan penelitian komparasi yang artinya perbandingan. Penelitian komparasi pada dasarnya adalah untuk mengetahui atau membandingkan ada tidaknya perbedaan antara dua sampel penelitian (Yusri, 2009)

Penelitian ini melibatkan dua perlakuan yang berbeda antara dua kelompok sehingga bila ditinjau dari perlakuannya, maka penelitian ini menggunakan metode eksperimen. Penelitian eksperimen dengan non randomized control group pre-test post-test design. Maka dapat digambarkan sebagai berikut:

Tabel 1. Desain Penelitian

\begin{tabular}{cccc}
\hline Kelas & Pre-test & Perlakuan & Post-test \\
\hline Kelas Eksperimen 1 & $\mathrm{T}_{1}$ & $\mathrm{X}_{1}$ & $\mathrm{~T}_{2}$ \\
\hline Kelas Eksperimen 2 & $\mathrm{T}_{1}$ & $\mathrm{X}_{2}$ & $\mathrm{~T}_{2}$ \\
\hline
\end{tabular}

Berdasarkan Tabel 1. dapat disimpulkan bahwa dalam penelitian ini peneliti menggunakan dua kelas yaitu kelas eksperimen 1 dengan menggunakan model pembelajaran Make a Match dan kelas eksperimen 2 menggunakan model pembelajaran Pair Checks. Dimana kedua kelas eksperimen ini sama-sama diberikan pre-test dan post-test yang sama tetapi yang membedakannya pada perlakuan dalam proses pembelajaran yaitu dengan menggunakan langkah-langkah model pembelajaran yang berbeda. 
Selanjutnya peneliti menggunakan teknik pengambilan sampel nonprobability sampling yaitu setiap anggota tidak memiliki peluang atau kesempatan yang sama sebagai sampel. Dimana populasi di kelas VII ada 92 siswa. Maka, teknik yang digunakan dengan cara purposive sampling yaitu pengambilan sampel dengan maksud dan tujuan tertentu. Sehingga, yang menjadi sampelnya adalah kelas $\mathrm{VII}_{2}$ b dengan jumlah 16 siswa sebagai kelas eksperimen I yaitu dengan menggunakan model pembelajaran Make a Match dan kelas $\mathrm{VII}_{1}$ a dengan jumlah 16 siswa sebagai kelas eksperimen II yaitu dengan menggunakan model pembelajaran Pair Checks. Dalam hal ini, teknik pengumpulan data peneliti menggunakan instrumen tes hasil belajar yaitu tes pada ranah kognitifnya adalah C1 sampai C6 dengan 6 soal berbentuk uraian.

Dalam pengembangan instrumen untuk menguji sebuah instrumen soal maka dilakukan uji validitas, uji reliabilitas, tingkat kesukaran tes, dan daya pembeda. Ketika peneliti telah melaksanakan pengembangan instrumen soal maka dapat diketahui berapa soal yang dapat dipakai pada penelitian tersebut. Sehingga teknik penelitian ini pada tahap pertama pre-test dan tahap kedua post-test. Dalam hal ini juga peneliti menggunakan teknik analisis data yaitu 1) analisis statistik deskriptif meliputi mean, median, modus, variansi, dan standar deviasi; 2) analisis statistik inferensial meliputi uji nomalitas, uji homogenitas, dan uji hipotesis dengan menggunakan software SPSS v.22.

\section{HASIL PENELITIAN DAN PEMBAHASAN}

Untuk menganalisis suatu hasil pengolahan data dalam penelitian maka dapat dilaksanakan dengan teknik analisis deskriptif dan teknik analasis inferensial dalam mengetahui perbedaan hasil belajar matematika sebagai berikut:

Tabel 2. Perbedaan Hasil Belajar Matematika Pre-test Siswa Kelas Eksperimen I dan kelas Eksperimen II

\begin{tabular}{cccccc}
\hline \multicolumn{2}{c}{ Kelas Eksperimen $\left.\mathrm{I}_{\left(\mathrm{VII}_{2}\right.} \mathrm{b}\right)$} & \multicolumn{3}{c}{ Kelas Eksperimen II $\left(\mathrm{VII}_{1} \mathrm{a}\right)$} \\
\hline Nilai & Frekuensi & $\%$ & Nilai & Frekuensi & $\%$ \\
\hline 29 & 1 & $6,25 \%$ & 29 & 2 & $12,5 \%$ \\
\hline 33 & 2 & $12,5 \%$ & 33 & 2 & $12,5 \%$ \\
\hline
\end{tabular}




\begin{tabular}{|c|c|c|c|c|c|}
\hline 38 & 1 & $6,25 \%$ & 38 & 3 & $18,75 \%$ \\
\hline 42 & 3 & $18,75 \%$ & 42 & 3 & $18,75 \%$ \\
\hline 46 & 1 & $6,25 \%$ & 50 & 2 & $12,5 \%$ \\
\hline 50 & 4 & $25 \%$ & 54 & 4 & $25 \%$ \\
\hline 54 & 3 & $18,75 \%$ & - & - & - \\
\hline 58 & 1 & $6,25 \%$ & - & - & - \\
\hline Jumlah & 16 & $100 \%$ & Jumlah & 16 & $100 \%$ \\
\hline Mean & 45.31 & & Mean & 42.50 & \\
\hline Median & 48.00 & & Median & 42.00 & \\
\hline Mode & 50 & & Mode & 54 & \\
\hline $\begin{array}{c}\text { Std. } \\
\text { Deviation }\end{array}$ & 8.685 & & $\begin{array}{c}\text { Std. } \\
\text { Deviation }\end{array}$ & 9.121 & \\
\hline Variance & 75.429 & & Variance & 83.200 & \\
\hline Range & 29 & & Range & 25 & \\
\hline Minimum & 29 & & Minimum & 29 & \\
\hline Maximum & 58 & & Махітит & 54 & \\
\hline
\end{tabular}

Berdasarkan pengolahan data pada Tabel 2. dapat dilihat pada kelas eksperimen I cenderung memusat ke angka rata-rata sebesar 45,31 termasuk dalam kriteria kurang maka varians dan standar deviasi semakin besar. Standar deviasi sebesar 9 sehingga dapat disimpulkan bahwa data di atas memusat ke nilai 45,31 dan data tersebut menyebar sebesar 0 - 9 satuan dari rata-ratanya. Sedangkan pada kelas eksperimen II dapat dilihat bahwa pada kelas eksperimen II cenderung memusat ke angka rata-rata sebesar 42,50 termasuk dalam kategori kurang maka varians dan standar deviasi semakin besar. Standar deviasi sebesar 9 sehingga dapat disimpulkan bahwa data di atas memusat ke nilai 42,50 dan data tersebut menyebar sebesar 0 - 9 satuan dari rata-ratanya. Dimana perolehan ini lebih rendah dibandingkan dengan perolehan hasil belajar Matematika siswa dikelas eksperimen I.

Tabel 3. Perbedaan Hasil Belajar Matematika Post-test Siswa Kelas Eksperimen I dan kelas Eksperimen II

\begin{tabular}{cccccc}
\hline \multicolumn{2}{c}{ Kelas Eksperimen $\left.\mathrm{I}_{(\mathrm{VII}} \mathrm{b}\right)$} & \multicolumn{3}{c}{ Kelas Eksperimen $\left.\mathrm{II}_{(\mathrm{VII}} \mathrm{a}\right)$} \\
\hline Nilai & Frekuensi & $\%$ & Nilai & Frekuensi & $\%$ \\
\hline 75 & 2 & $12,5 \%$ & 71 & 4 & $25 \%$ \\
\hline 79 & 1 & $6,25 \%$ & 75 & 2 & $12,5 \%$ \\
\hline
\end{tabular}




\begin{tabular}{|c|c|c|c|c|c|}
\hline 83 & 3 & $18,75 \%$ & 79 & 3 & $18,75 \%$ \\
\hline 88 & 4 & $25 \%$ & 83 & 2 & $12,5 \%$ \\
\hline 92 & 4 & $25 \%$ & 88 & 2 & $12,5 \%$ \\
\hline 96 & 2 & $12,5 \%$ & 92 & 3 & $18,75 \%$ \\
\hline Jumlah & 16 & $100 \%$ & Jumlah & 16 & $100 \%$ \\
\hline Mean & 86.88 & & Mean & 80.56 & \\
\hline Median & 88.00 & & Median & 79.00 & \\
\hline Mode & $88^{\mathrm{a}}$ & & Mode & 71 & \\
\hline $\begin{array}{c}\text { Std. } \\
\text { Deviation }\end{array}$ & 6.662 & & $\begin{array}{c}\text { Std. } \\
\text { Deviation }\end{array}$ & 7.958 & \\
\hline Variance & 44.383 & & Variance & 63.329 & \\
\hline Range & 21 & & Range & 21 & \\
\hline Minimum & 75 & & Minimum & 71 & \\
\hline Maximum & 96 & & Maximum & 92 & \\
\hline
\end{tabular}

Berdasarkan pengolahan data pada Tabel 3. dapat dilihat bahwa pada kelas eksperimen I cenderung memusat ke angka rata-rata sebesar 86,88 termasuk dalam kriteria baik sekali maka varians dan standar deviasi semakin kecil. Standar deviasi sebesar 7 sehingga dapat disimpulkan bahwa data di atas memusat ke nilai 86,88 dan data tersebut dapat menyebar sebesar 0 - 7 satuan dari rata-ratanya. Sedangkan pada kelas eksperimen II cenderung memusat ke angka rata-rata sebesar 80,56 termasuk dalam kriteria baik sekali maka varians dan standar deviasi semakin besar. Standar deviasi sebesar 8 sehingga dapat disimpulkan bahwa data di atas memusat ke nilai 80,56 dan data tersebut menyebar sebesar $0-8$ satuan dari rata-ratanya.

\section{Hasil Belajar Matematika dengan Menggunakan Model} Pembelajaran Make a Match pada Materi Bilangan Bulat di Kelas VII MTs IB Silaping

Berdasarkan pengolahan data pada Tabel 2 dan 3 di kelas eksperimen I (Model Pembelajaran Make a Match) dapat diketahui bahwa nilai rata-rata hitung (mean) hasil belajar pre-test (sebelum diberi perlakuan) adalah 45,31. Sedangkan ketika sudah diberikan perlakuan (post-test) menggunakan model pembelajaran Make a Match diketahui 
bahwa nilai rata-rata hitung (mean) hasil belajarnya sebesar 86,88. Dapat disimpulkan bahwa nilai rata-rata post-test lebih meningkat dari pada nilai rata-rata pre-test.

Dalam hal ini didukung oleh temuan hasil penelitian (Lelya Hilda, 2018) yang menyatakan bahwa model pembelajaran kooperatif teknik Make a Match memiliki pengaruh terhadap hasil belajar matematika siswa, karena siswa semangat dan antusias dalam menerima materi pelajaran. Kemudian setiap kelompok siswa aktif dalam menjawab soal yang diberikan.

\section{Hasil Belajar Matematika dengan Menggunakan Model} Pembelajaran Pair Checks pada Materi Bilangan Bulat di Kelas VII MTs IB Silaping

Berdasarkan pengolahan data pada Tabel 2 dan 3 di kelas eksperimen II (Model Pembelajaran Pair Checks) dapat diketahui bahwa nilai rata-rata hitung (mean) hasil belajar pre-test (sebelum diberi perlakuan) adalah 42,50. Sedangkan ketika sudah diberikan perlakuan (post-test) menggunakan model pembelajaran Pair Checks diketahui bahwa nilai rata-rata hitung (mean) hasil belajarnya sebesar 80,56. Dapat disimpulkan bahwa nilai rata-rata post-test lebih meningkat dari pada nilai rata-rata pre-test.

Dalam hal ini didukung oleh temuan hasil penelitian (Rohmatika, 2017) yang menyatakan bahwa model pembelajaran tipe Pair Checks dengan bantuan LKS dapat meningkatkan hasil belajar matematika siswa, karena dalam proses pembelajaran siswa lebih aktif, kedekatan antar siswa, belajar menerima pendapat orang lain dan melatih kemampuan komunikasi baik pada guru maupun partnernya.

\section{Perbedaan Hasil Belajar Matematika dengan menggunakan Model Pembelajaran Make a Match dan Model Pembelajaran Pair Checks pada Materi Bilangan Bulat di Kelas VII MTs IB Silaping}

Pengolahan data ini untuk mengetahui apakah terdapat perbedaan yang signifikan antara hasil belajar matematika dengan menggunakan model pembelajaran Make a Match dan model pembelajaran Pair Checks 
pada materi bilangan bulat di kelas VII MTs IB Silaping. Sehingga peneliti menggunakan teknik analisis inferensial pada data post-test yaitu: 1. Uji Normalitas

Untuk menguji normalitas digunakan Uji Kolmogrov-smirnov dengan taraf signifikansi 5\% atau 0,05.

Tabel 4. Hasil Uji Normalitas Data Post-test Kelas Eksperimen 1 dan Kelas Eksperimen 2

\begin{tabular}{c|c|c|c|c|c|c|c}
\hline \multicolumn{1}{c}{ Tests of Normality } \\
\hline & Kelas & \multicolumn{2}{|c|}{ Kolmogorov-Smirnov } & \multicolumn{3}{|c}{ Shapiro-Wilk } \\
\cline { 2 - 8 } & Statistic & $d f$ & Sig. & Statistic & $d f$ & Sig. \\
\hline Nilai Post-test & $\begin{array}{c}\text { Post-test } \\
\text { Eksperimen 1 }\end{array}$ & .192 & 16 & .117 & .921 & 16 & .174 \\
\cline { 2 - 8 } & $\begin{array}{c}\text { Post-test } \\
\text { Eksperimen 2 }\end{array}$ & .140 & 16 & $.200^{*}$ & .888 & 16 & .051 \\
\hline
\end{tabular}

Berdasarkan Tabel 4 diketahui bahwa nilai signifikansi post-test eksperimen 1 yaitu 0,117>0,05 dan post-test eksperimen 2 yaitu 0,200 > 0,05 , maka berdistribusi normal. Sehingga analisis perbedaan data hasil belajar post-test menggunakan statistik parametriks dengan $t$-test.

2. Uji Homogenitas

Untuk menguji homogenitas digunakan data post-test dengan taraf signifikansi $5 \%$ atau 0,05 .

Tabel 5. Hasil Uji Homogenitas Data Post-test

\begin{tabular}{c|c|c|c}
\hline \multicolumn{5}{c}{ Test of Homogeneity of Variances } \\
\hline Levene Statistic & $d f_{1}$ & $d f_{2}$ & Sig. \\
\hline 1.050 & 1 & 30 & .314 \\
\hline
\end{tabular}

Berdasarkan perolehan hasil pada Tabel 5, maka sesuai dengan kriteria yang berlaku diketahui nilai signifikansi (sig.) adalah sebesar $0,314>0,05$. Sehingga dapat disimpulkan bahwa varians data post-test kelas eksperimen 1 dan kelas eksperimen 2 adalah sama atau homogen. 
3. Uji Perbedaan Rata-Rata (t-test)

Untuk menjawab rumusan perbedaan hasil belajar matematika tersebut digunakan uji hipotesis (t-test) seperti yang dijelaskan dalam Tabel 6.

Tabel 6. Ringkasan Hasil Pengujian Hipotesis

\begin{tabular}{|c|c|c|c|c|c|c|}
\hline No & $\begin{array}{c}\text { Nilai } \\
\text { Statistika }\end{array}$ & $\begin{array}{c}\text { Kelas } \\
\text { Eksperimen I }\end{array}$ & $\begin{array}{c}\text { Kelas } \\
\text { Eksperimen } \\
\text { II }\end{array}$ & $\mathrm{t}_{\text {hitung }}$ & $\mathrm{t}_{\text {tabel }}$ & $\begin{array}{c}\text { Kesim } \\
\text { pulan }\end{array}$ \\
\hline 1 & Rata-rata & 86,88 & 80,56 & \multirow{4}{*}{2,433} & \multirow{4}{*}{2,042} & \multirow{4}{*}{$\begin{array}{c}\mathrm{H}_{\mathrm{a}} \\
\text { diteri } \\
\mathrm{ma}\end{array}$} \\
\hline 2 & $\begin{array}{l}\text { Standar } \\
\text { Deviasi }\end{array}$ & 6,662 & 7,958 & & & \\
\hline 3 & Varians & 44,383 & 63,329 & & & \\
\hline 4 & $\begin{array}{l}\text { Jumlah } \\
\text { Sampel }\end{array}$ & 16 & 16 & & & \\
\hline
\end{tabular}

Tabel 6 menunjukkan hasil pengujian pada taraf signifikansi $\alpha=0,05$ dan $d k=n_{1}+n_{2}-2=16+16-2=30$ dengan $t_{\text {hitung }}=2,433$ dan $t_{\text {tabel }}=2,042$ ini menunjukkan bahwa thitung $>t_{\text {tabeel }}$. Berdasarkan keputusan sebelumnya maka menerima $\mathrm{H}_{\mathrm{a}}$ dan menolak $\mathrm{H}_{0}$. Dari hasil analisis uji Independent Sample T-test menggunakan SPSS v.22 dan berdasarkan perhitungan di atas maka hipotesis ini memberikan temuan bahwa "Terdapat Perbedaan yang Signifikan antara Hasil Belajar Matematika dengan Menggunakan Model Pembelajaran Make a Match dan Model Pembelajaran Pair Checks pada Materi Bilangan Bulat di Kelas VII MTs IB Silaping".

Temuan ini sejalan dengan penelitian (Nurhana, 2018) yang menyatakan bahwa model pembelajaran Kooperatif Tipe Make a Match lebih baik dan lebih efektif untuk diterapkan dalam kegiatan pembelajaran matematika. Hal ini disebabkan model pembelajaran Kooperatif Tipe Make a Match cenderung lebih menarik perhatian siswa dan berpusat pada keaktifan siswa sehingga tercapainya suasana kegembiraan antar siswa dan munculnya dinamika saling kerjasama antar sesama siswa. 


\section{SIMPULAN}

Model pembelajaran Make a Match baik digunakan dalam pembelajaran matematika pada materi bilangan bulat di kelas VII MTs IB Silaping yang dibuktikan dengan hasil belajar matematika dengan perhitungan deksriptif berupa nilai rata-rata post-test 86,88 yang lebih meningkat dari pada nilai pre-test yaitu 45,31. Model pembelajaran Pair Checks baik digunakan dalam pembelajaran matematika pada materi bilangan bulat yang dibuktikan dengan hasil belajar matematika dengan perhitungan deksriptif berupa nilai rata-rata post-test 80,56 yang lebih meningkat dari pada nilai pre-test yaitu 42,50 . Terdapat perbedaan yang signifikan antara hasil belajar matematika dengan menggunakan model pembelajaran Make a Match dan model pembelajaran Pair Checks pada materi bilangan bulat di kelas VII MTs IB Silaping. Hal ini berdasarkan hasil temuan yang menyatakan bahwa hipotesis $\mathrm{H}_{\mathrm{a}}$ diterima dengan perhitungan uji- $t$ perbedaan menunjukkan hasil pengujian pada taraf signifikansi $\alpha=0,05$ dan $d k=n_{1}+n_{2}-2=16+16-2=30$ dengan $t_{\text {hitung }}=2,433$ dan $t_{\text {tabel }}=2,042$ ini menunjukkan bahwa $t_{\text {hitung }}>t_{\text {tabel }}$. Dengan memperoleh nilai rata-rata hasil belajar matematika yang menggunakan pembelajaran dengan model pembelajaran Make a Match lebih tinggi dibandingkan dengan hasil belajar matematika yang menggunakan pembelajaran dengan model pembelajaran Pair Checks.

\section{DAFTAR PUSTAKA}

Ainur, Citra Maharani. (2016). Pengaruh Strategi Pembelajaran Terhadap Hasil Belajar Matematika Ditinjau Dari Keaktifan Belajar Siswa. Skripsi. Surakarta: Universitas Muhammadiyah Surakarta.

Danoebroto, S. W. (2015). Teori Belajar Konstruktivis Piaget Dan Vygotsky. Jurnal Of Mathematics And Education, Volume 2(No. 3).

Gillies, Robbyn M. (2016). Cooperative Learning: Review of Research and Practive. Australian Journal of Teacher Education, Vol 41 (3). Hamalik, O. (2011). Kurikulum dan Pembelajaran. Jakarta: Bumi Aksara. Iqbal, Muhammad \& Karim, Asrul. (2018). Upaya Meningkatkan Hasil Belajar Siswa Pada Materi Operasi Hitung Bilangan Bulat Dengan 
Menggunakan Media Kartu Bermuatan Berbasis Model

Pembelajaran NHT Pada Siswa Kelas V MIN 49 Bireuen. Jurnal

Pendidikan Almuslim, Vol VI (No 2).

Karomah, Mamluatul \& Sudiman, Budiyono. 2013. Peningkatan Hasil

Belajar Operasi Penjumlahan Bilangan Bulat Dengan Media

Wayang di Jalan Bilangan Sekolah Dasar. JPGSD, Vol 1 ( No 2).

Lelya Hilda, D. (2018). Pengaruh Model Pembelajaran Kooperatif Tipe

Make A Match Berbantuan Media Grafis Terhadap Hasil Belajar

Matematika Siswa Pada Materi Pokok Segiempat Di Kelas VII MTs

Negeri Model Padangsidimpuan. Jurnal Logaritma, Volume 06(No. $1)$.

Nahar, N. I. (2016). Penerapan Teori Belajar Behavioristik Dalam Proses Pembelajaran. Jurnal Ilmu Pengetahuan Sosial, Volume 1.

Nurhana, F. (2018). Perbedaan Hasil Belajar Siswa yang Diajarkan dengan Model Pembelajaran Koperatif Tipe Make A Match dan Tipe Jigsaw pada Materi operasi Aljabar di kelas VIII MTs AlFauzan Aek Paing Labuhanbatu. Skripsi UINSU.

Pianda, R. \& D. (2018). Strategi \& Implementasi Pembelajaran Matematika di Depan Kelas. Jawa Barat: CV Jejak.

Purwanto. (2017). Evaluasi Hasil Belajar. Yogyakarta: Pustaka Pelajar.

Rohmatika. (2017). Pengaruh Model Pembelajaran Koperatif Tipe Pair

Checks Berbantuan Lembar Kerja Siswa (LKS) Terhadap Hasil

Belajar Matematika Siswa Kelas VII MTs Ma'arif Udanawu. Skripsi IAIN Tulungagung.

Santi Ariati, D. (2019). Pengaruh Model Pembelajaran Kooperatif Teknik

Make A Match Terhadap Hasil Belajar Matematika Siswa Kelas

VIII SMP Negeri 21 Pekanbaru. Jurnal Penelitan Pendidikan Dan

Pembelajaran Matematika (Aksiomatik), Volume 7(No. 2).

Shoimin, A. (2014). 68 Model Pembelajaran Inovatif dalam Kurikulum 2013. Yogyakarta: Ar-Ruzz Media.

Siregar, N. F. (2016). Pendekatan Problem Posing Dalam Pembelajaran Matematika. Jurnal Logaritma, Volume 4(No. 02 Juli).

Siregar, N. F. (2020). Minat Belajar Matematika pada Siswa SMP Negeri

7 Padangsidimpuan. Jurnal Logaritma, Volume 8 (No. 2 Desember). 
Yudhanegara, K. E. L. \& M. R. (2015). Penelitian Pendidikan Matematika. Bandung: PT Refika Aditama.

Yusri. (2009). Statistika Sosial. Yogyakarta: Graha Ilmu. 
62 | Lintang, dkk: Perbedaan Hasil Belajar Matematika ... 